\title{
演題番号 7
}

\section{新生児期に対する体外循環方法の再検討}

\author{
社会保険中央病院 S M I センター \\ 早 川 政 史 間 部弘 \\ 同施設 研究生 \\ 寺島孝保浅野敦 栄元謙之介
}

\section{I . 目 的}

当院に心蔵外科が開設されてから14年が経過し， 1980年頃から小児症例が多くなってきている. こ 乙数年においては，年間症例数の約 7 割加乳幼児 および新生児症例で, 年齢にかかわらず福雑心奇 形に対する，開心手術が多く施行されるようにな っている. てうした症例倿対し，おおようの申し 合わせはなされているものの, カニューレ，体外 循環中の体温などの取り決めは随時なされている のが現状であり，確立された体外偱環が每回施行 されているわけではない。

今回，新生児期江超低体温，循環停止法を併用 した体外循環を調查し，血行動態，ガス動態，低 体温時注りるる灌流量を再検討した。

\section{II. 症例およひ方法}

表 1 は1980年から1987年までの体外循環症例で
あるが，大半が先天性疾患であり 772 症例が施行 された. また，図1は1980年から1987年までの体 外循環症例数の推移であるが, 全体の約 3 割が 1 歳以下の乳览症例であり，その内 1 力月以下の症 例は，わずかながら增加傾向にあるようにみうけ

\section{表1体外循环应例（1980 1987年）}

\begin{tabular}{|c|c|c|c|c|c|c|c|c|c|}
\hline 童的入年度 & 1980 & 1081 & 1982 & 1983 & 1884 & 1885 & 1988 & 1987 & 合频 \\
\hline ASDE & 8 & 15 & 14 & 23 & 12 & 12 & 18 & 16 & 118 \\
\hline VSD & 22 & 28 & 30 & 22 & 28 & 34 & 28 & 31 & 220 \\
\hline$T \circ F$ & 21 & 10 & 12 & 11 & 12 & 7 & 11 & 17 & 101 \\
\hline TGA & 3 & 7 & 6 & 7 & 1 & 8 & 6 & 5 & 43 \\
\hline$E C D$ & 2 & 5 & 2 & 8 & 2 & $\mathbf{5}$ & 3 & 4 & 29 \\
\hline TAPVC & 4 & 3 & 6 & 8 & 8 & 4 & 8 & 4 & 43 \\
\hline 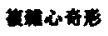 & 2 & 3 & 4 & 4 & 3 & 8 & 7 & 12 & 44 \\
\hline 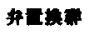 & 9 & 8 & 11 & 4 & 12 & 12 & 11 & 14 & 81 \\
\hline その借 & 16 & 8 & 8 & 13 & 15 & 11 & 11 & 11 & 83 \\
\hline 合 it & 87 & 85 & 83 & 88 & 94 & 102 & 89 & 114 & 772 \\
\hline
\end{tabular}

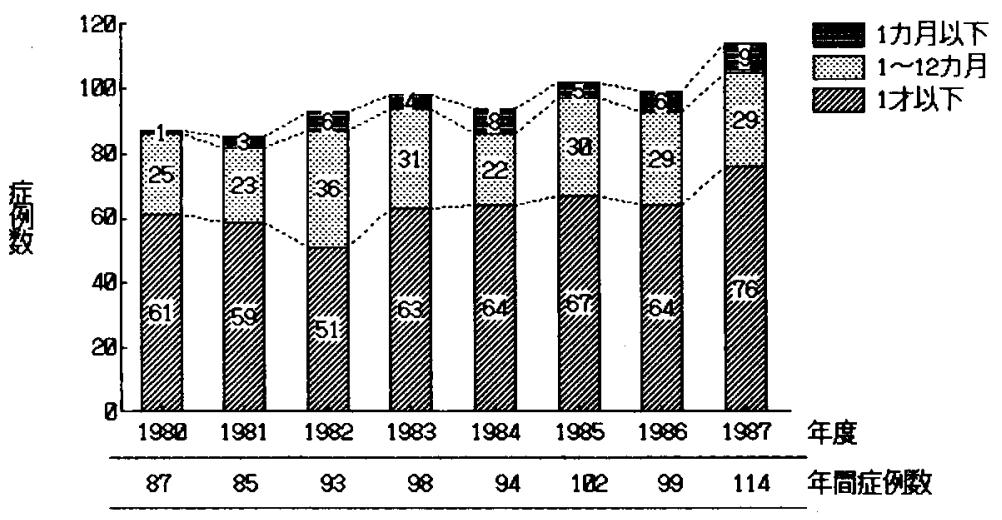

因 1 体外循环应列数（年度別） 
られる.また，図2においては，1歳以下の月齢 別の推移であるが，総数 267 症例のうち 1 力月以 下の症例が42症例を数え，これらの症例はほとん ど緊急的に手術が施行されている.

図 3 は，1 1 月以下筷患別のグラフであるが, TAPVCが約半数をしめ, 次いでV S D群の順番 になっている. てれら症例の平均体重は 3,085 ， 最大 4,2608 ，最小 1,4448 ，平均体表面積は 0.2034 mであった.

こうした症例に対して表 2 のでとく，準謈をお こなっているが，医師の指示で体重 $5 \mathrm{Kg}$ 以下に対 しては，すべてへパリン化新鮮血を充填している.
表 3 は実際の準備表である．これは患者の術前 身長, 体重, ヘマトクリット值をもとに計算され たものである.

写真 1 は，新生児症例に対し使用されるカテー テル類であるが, 市販のものだけでは全症例を補 えず，特注による金属カテーテルが用意されたり， 本来, 別の目的に市販されているあのを代用した こともある。

\section{III. 䊅果およひ考察}

図 4 は, 循環停止症例の血行動態の变化を現し ている. 平均動脈圧は $50 \mathrm{~mm} \mathrm{Hg}$ 前後に維持し, 静

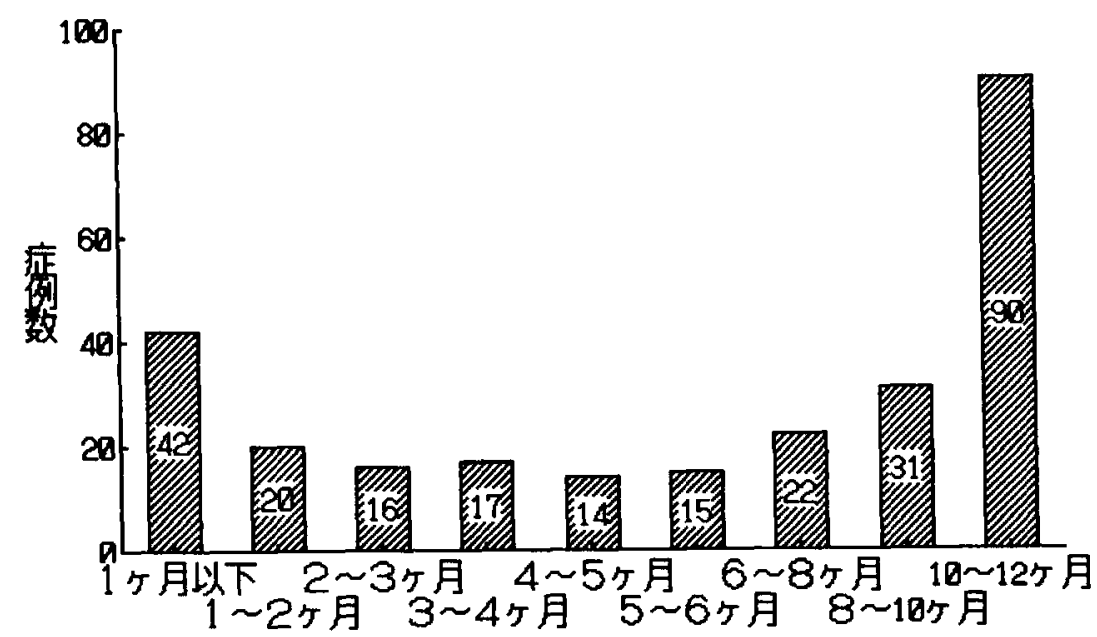

图 21 端以下の年数分布

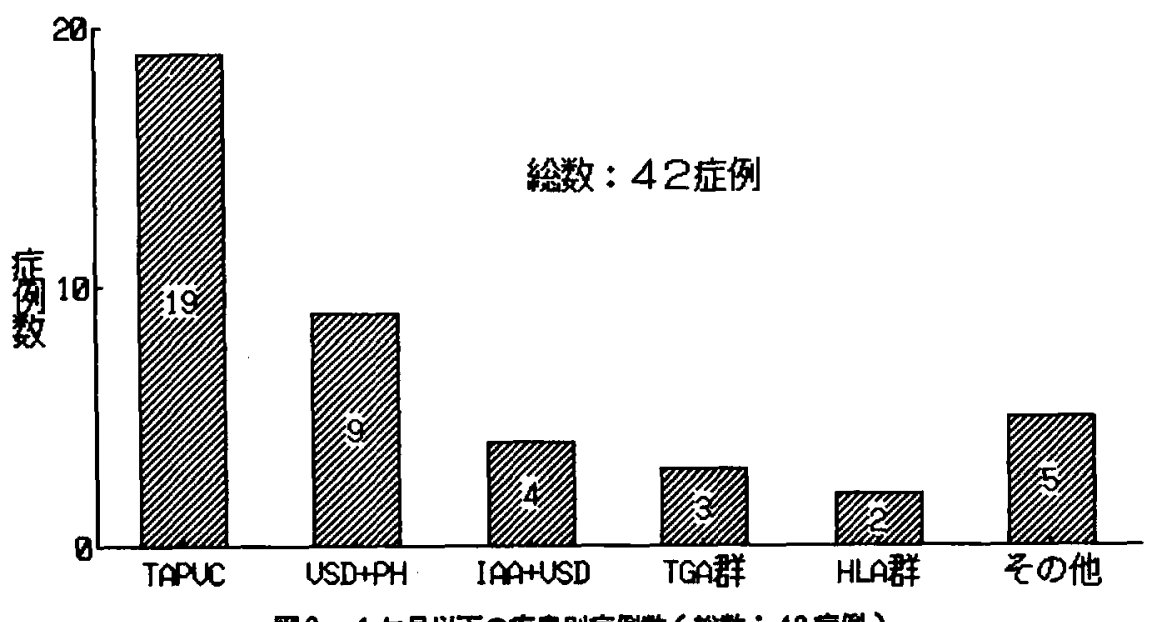

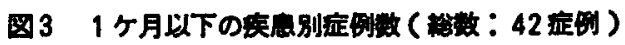


表 2 体外循理策潇表

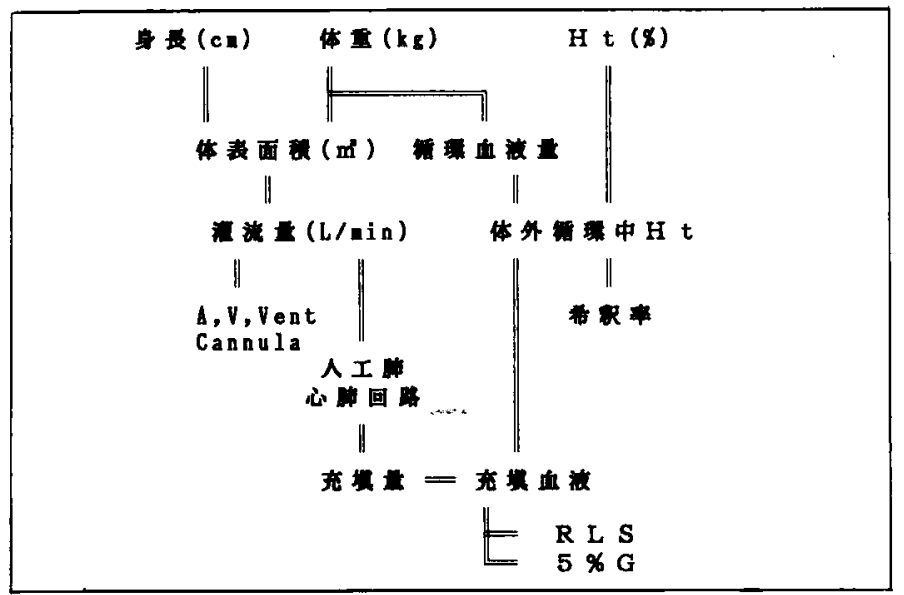

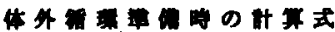

体表面的

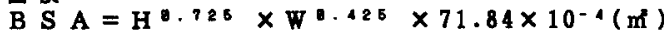

上式て $0.6 \mathrm{~m}$ 以下虾

B S A $=\mathrm{H}^{6} .3064 \times \mathrm{W}^{0.5378} \times 242.65 \times 10^{-4}\left(\mathrm{~m}^{2}\right)$

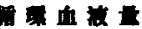

4 $10 \mathrm{~kg}$ 上 $\mathrm{CBV}=\mathrm{W} \times 80(\mathrm{al})$

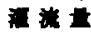

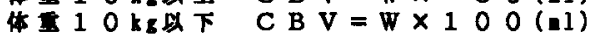

\section{B S A}

$\sim 0.5$ P B F $=B$ S A $\times 2.8(\mathrm{~L} / \mathrm{ain})$

$0.5 \sim 0.8$ P B F $=B$ S A $\times 2.6(\mathrm{~L} / \mathrm{ain})$

$0.8 \sim 1.2 \quad$ P B F $=$ B S A $\times 2.4(\mathrm{~L} / \mathrm{An})$

$1.2 \sim \quad$ P B F $=B S A \times 2.2(\mathrm{~L} / \mathrm{Bin})$

体的中 $\mathrm{Ht}$ 刍踏

ECCH $t=($ CBVXHt+P.Blood $\times 40) \div(C B V+P . V o l)(x)$

Henodairution $=\left(P . V_{0} l-P . B l o o d\right) \div\left(C B V+P . V_{0} l\right) \times 100(X)$

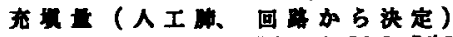

P. Voluge = P. Blood+RLS+5\%Glucose (nI)

$R L S=(P . V o l-P . B 100 d) \div 2(n 1)$

人工回萡

$58 G=\left(P . V_{0 l}-P . B 100 d\right) \div 2(n 1)$

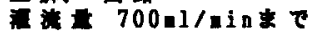
1500 el/ain 3500 -1/Rin 60001/.int
Capiox II 08+CH-MS (小児用回品) Capiox II $16+$ CH-MS

VPCHL + CH-HM（中人用回虫） Sarns16310+CH-HL（大人用回明）

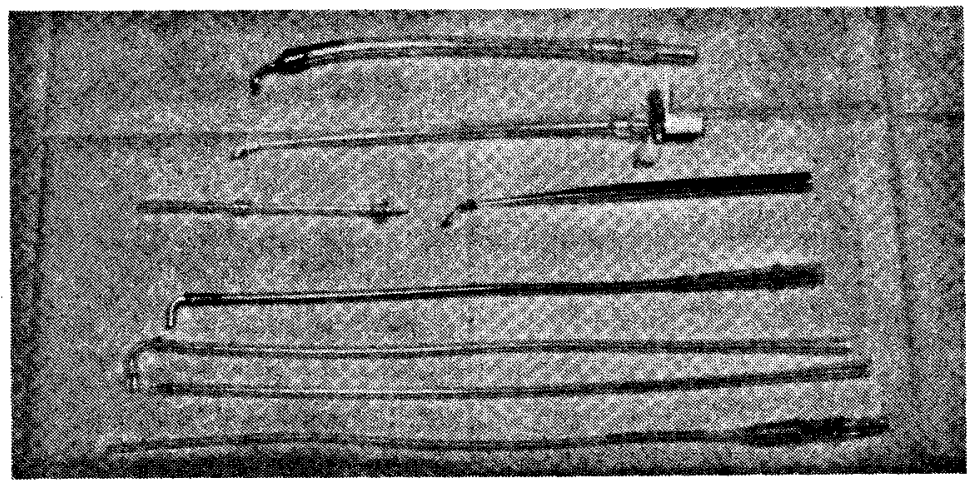

写基 1 
表 3 準備表の見本

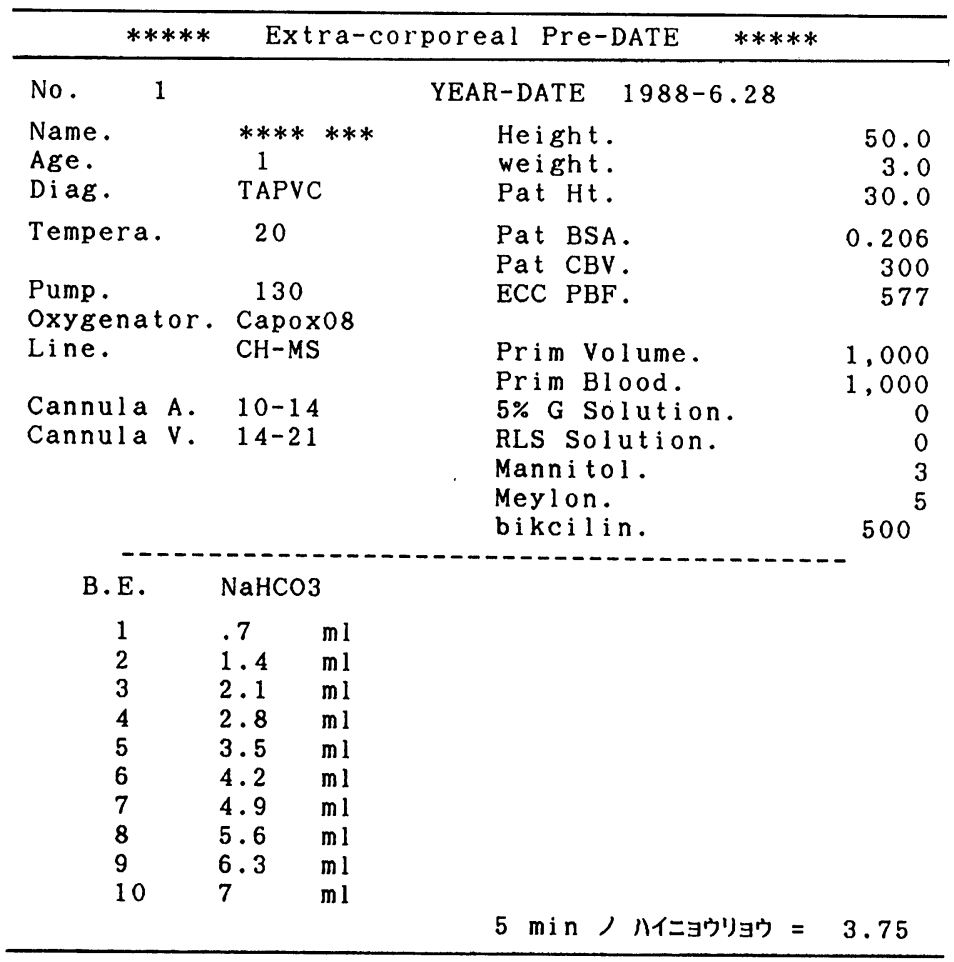

脈圧は高くならないようにした，ただ超低体温時 は最低尿量が維持されているかを監視し，灌流量 において，一時的に脱血による低流量灌流をおて を選択している.

Rrwarming時においては，平均左房圧をむと なうこと屯多く, 平均動脈圧は30 40 mm Hg 代に に，患者のボリュームを調節している．体重が3

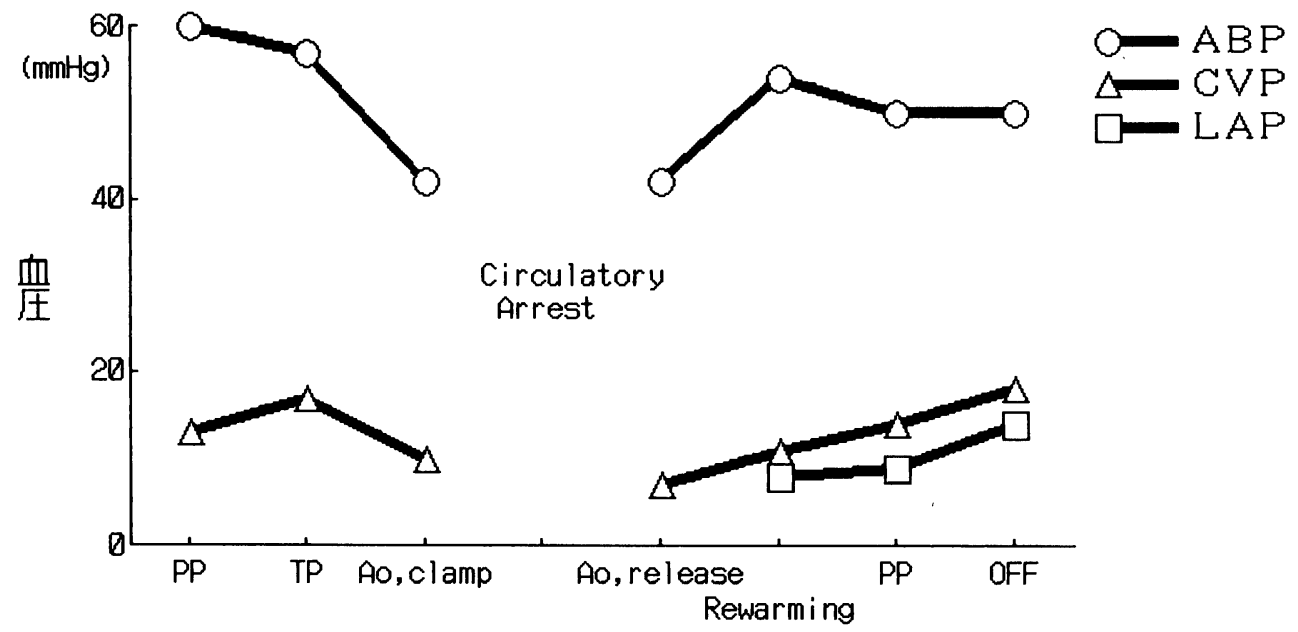

図 4 血行動墛の变化 
$\mathrm{Kg}$ 前後の患者では $5 \mathrm{ccc}, 10 \mathrm{cc}$ 程度のボリューム変 化で血圧が変動するため, 血圧表示を常に監視し, $1 \sim 2 \mathrm{~mm} \mathrm{Hg}$ 以内の変化でコントロールする必要 があった．灌流量は図 5 に示すとおりであるが， 体表面積当り $2 \ell / \min$ 前後であり, 予定灌流量か らするといくぶん低灌流量であった. 全血充填に より循環中のへマトクリット值は $35 \%$ 前後となり, 血液粘性により末梢血管抵抗值が上昇し, 灌流量 を増加させにくい原因となっている可能性が考え 、られる. また, 超低体温もその原因のひとつと思
われる。

図 6 はガス動態の変化である. 数年前まで $\mathrm{Ka}$ plan の示す方法により体外循環中, 脳血流量を 増やす目的にて炭酸ガスを吹送し，呼吸性アシド ーシスの状態に調整していた方法である.しかし， こて数年図 7 に示すように，正常に近い血液ガス 值に調整する方法に変更してみた。その理由は, 当院では温度補正による血液ガス分析值で判断し ているため, 低体温時における $\mathrm{PaCO}_{2}$ 值は, 常 温時に比較するとかなりの高値となるため，果し

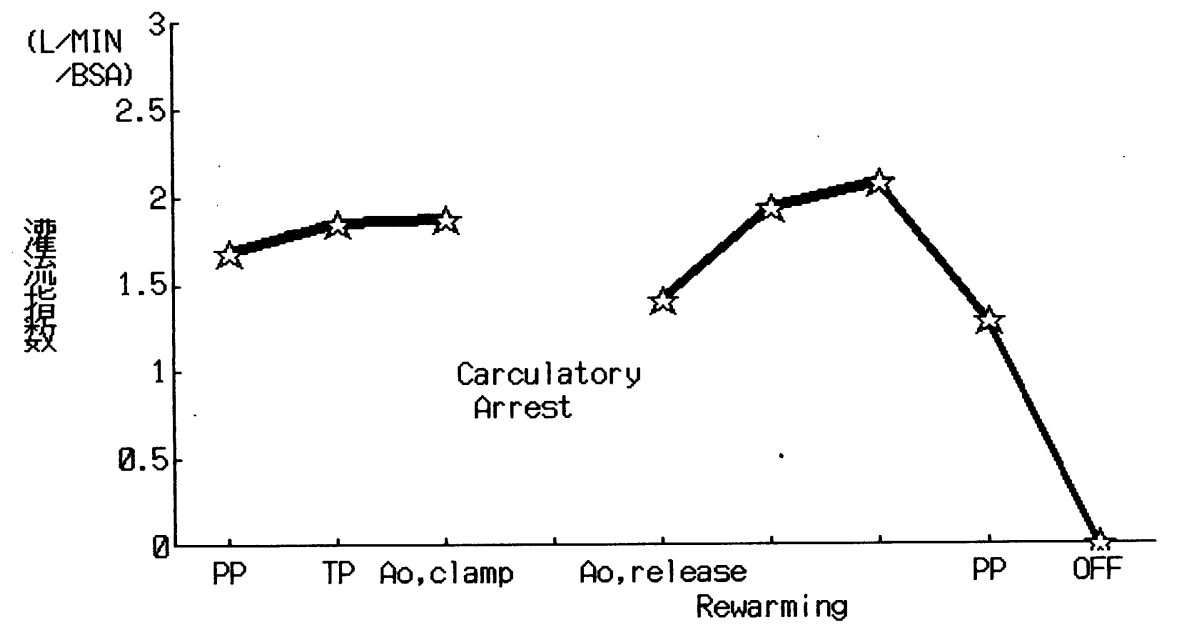

図 5 体表面積当りの 流指数変化

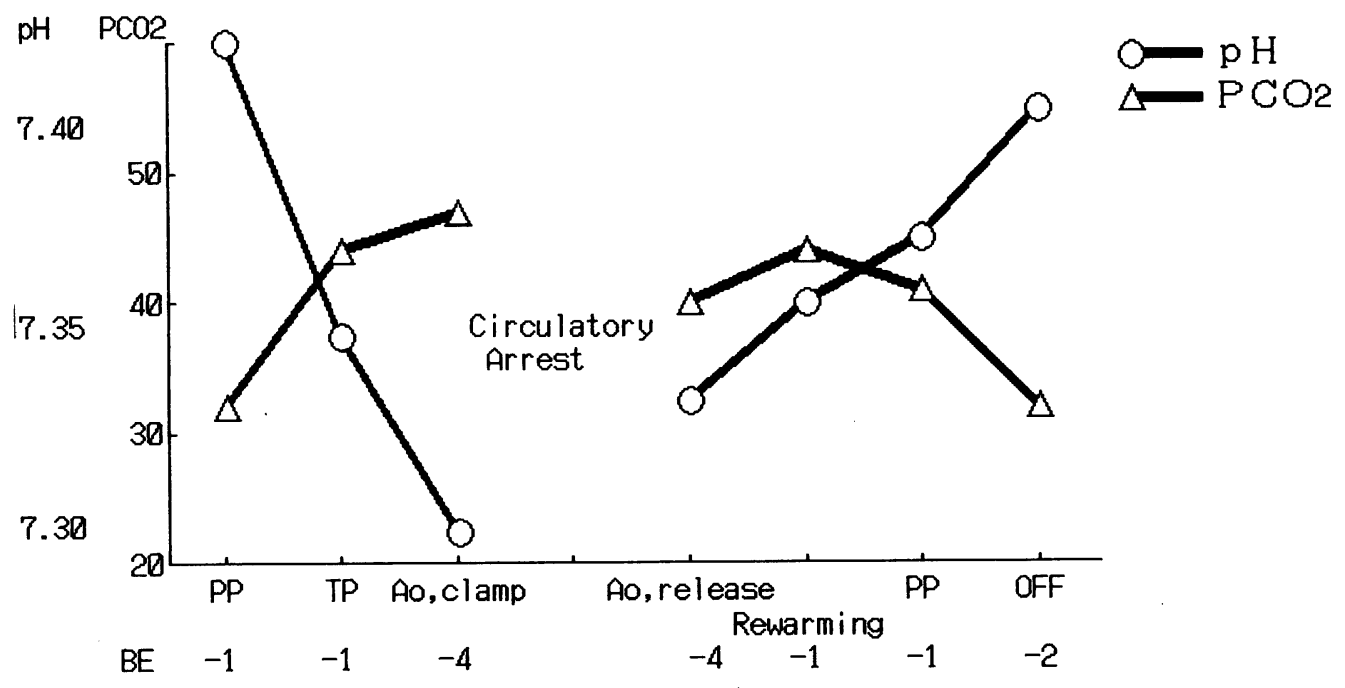

図 6 ガス動笖の変化 (呼吸性アシドーシス調整方法) 


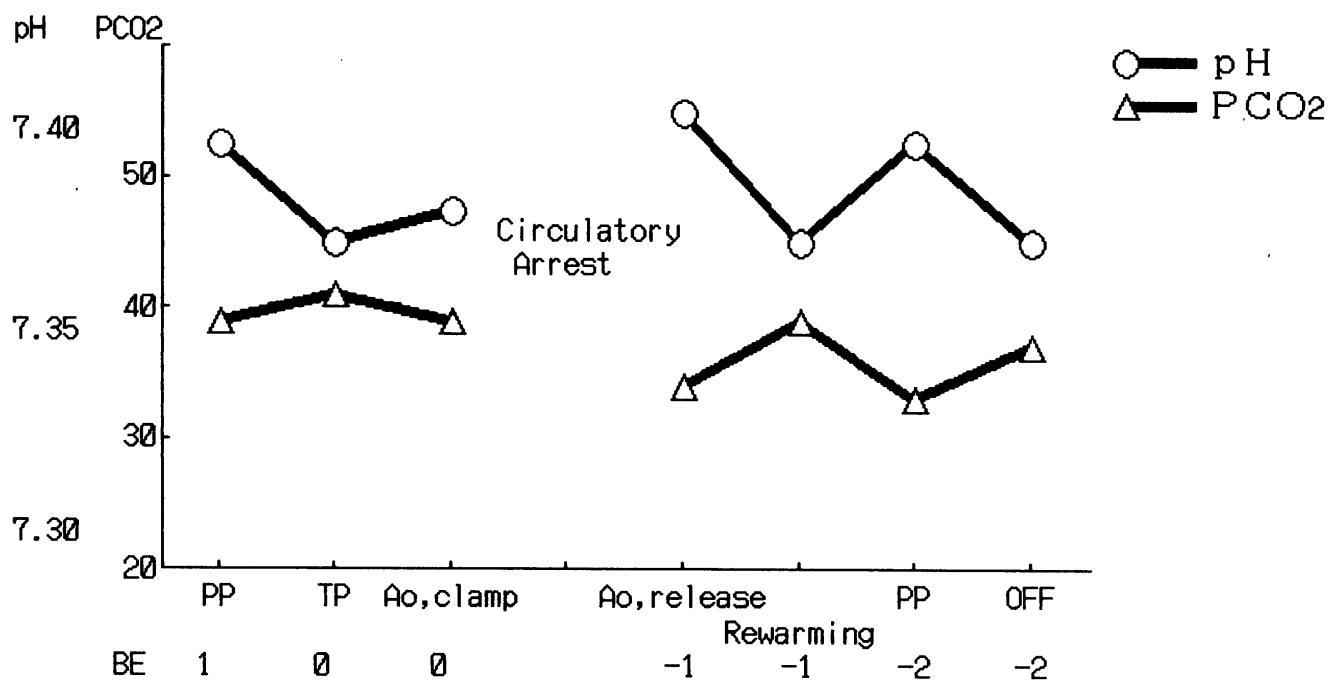

図 7 ガス動態の変化 (正常值調整方法)

てての調整が適切かを比較する目的にて調整方法 を変えてみた. その結果, 有意差はみられなかっ たが，体外循環中代謝性アシドーシスの補正例は わずかに減ってきているように思われる．42症例 のうち，代謝性アシドーシスの補正が必要になっ たものは20症例であった.しかし，緊急症例に関 しては術前の患者状態が悪いため, 体外循環によ るものなのか判断することが無理とも悪われた。

$\mathrm{PaO}_{2}, \mathrm{PvO}_{2}, \mathrm{SvO}_{2}$ に関しては図の中に記 載していないが, 混合静脈血の血液ガス分析値は 正常範囲内にあり，十分満たされているものと考 えられた. てれも全血充填により酸素運搬能力が 低下せず，低流量灌流を補っているのかむしれな い.

\section{IV. まとめ}

今後, 我々が留意するととは,

\section{1. 緊急的症例が多いため，迅速な準備を施行す} る.

新生児症例に対し全血充填を施行しているため， 緊急時院内採血による, ヘパリン化新鮮血が用意 される。乙のため時間的余裕がなく，他のME機 器準備ともかさなり, 体外循環開始まで迅速な対 応をしたいと考える.

\section{2. 適切な各種カテーテルの選択。}

必要以上に太いカテーテルの選択は, 動脈では カテーテルにより狭窄状態をつくるととがあり， 静脈においては血管内壁に密着し, 脱血を悪くし てしまう可能性が多い，適切な選択は重要な要素 の一つと思われ，市販の動静脈およびベントカテ 一テルでは十分補えず，当院独自のカテーテルを そろえる必要を感じた。

3. 微小循環バランスのコントロールが必要とさ れる。

基本的には成人も，小児，新生児むバランスの コントロールは同じであるが，わずかな血液バラ ンスの調整により，容易に心臓の加付加になるた め, 動静脈圧および左房圧によるバランスコント ロールは，必須と考えている。

\section{4. 超低体温時における灌流量の適切な選択.}

\section{$\mathrm{PVO}_{2}$ ，尿量確保。}

5. 充分な末梢循環の維持.

4,5 亿関しては，特に低体温時に問題となりや すく, 一時的な低流量灌流法を $\mathrm{PvO}_{2}$, 最低排尿 量等の維持で判断し，その時間をも考慮にいれ， 対応する方法がよいと考えられた。

\section{6. 無血手術視野の確保.}

無血手術視野を確保することは，迅速な手技， 手術時間の短縮につながり，パーフュージョンニ ストが考慮しなければならない一つと考えている. 
今回の発表は, 新生児期に対し,より生理的体 外循環を目指すための検討であったが，あまりに あ不確定事実が多く，なにが生理的で，なにが非 生理的であるか不明な状況であった。また。新生 児期では, 生体の各臓器がまだ育成されておらず, $\mathrm{PaCO}_{2}$ 值を高くすることの反応がどれだけ有意 義なのか, 血液希釈にすることに腎機能がどれほ ど期待できるかあ疑問であった。

とああれ正常な血行動態，ガス動態を維持する ためには，医師とのコミュニケーションを密にし， 常に各データーを監視報告し，その変化，異常に 対し速やかな対応を心がけることが必須であると 思われた。

\section{文献}

1）藤倉一郎：開心術のための人工心肺，形成社. 東京, 1976 。

2）藤本 淳：体外循環一その基礎と臨床，文光 堂. 東京, 1980 .

3) Joel , A. , Kaplan, M. D. : 心臟麻酔, 真興交易医書出版部. 東京, 1982 .

4）間部 弘：ガス動態よりみた体外循環，体外 循環技術, $7(12) ： 33,1981$ 。

5）早川政史：装置側からみた新生児体外循環, 体外循環技術, 10(18)：95，1984。

6) 早川政史：乳幼児体外循環について，体外循 環技術, 1222：27， 1986 .

7）早川政史：低体温時における乳幼児体外循環 の必要灌流量について，体外循環技術。1324： 25, 1987. 